\title{
PERUSAHAAN KECIL DENGAN PERTUMBUHAN TINGGI: PERSPEKTIF KEBIJAKAN PUBLIK
}

\author{
Didin Muhafidin \\ Universitas Padjadjaran \\ Email: didin_muhafidin@yahoo.co.id
}

\begin{abstract}
Abstrak
Penelitian ini bertujuan untuk mengetahui apakah ada tanda-tanda bahwa kebijakan publik mulai memahami bahwa tidak hanya pada perusahaan pemula yang dapat mencapai tingkat pertumbuhan yang tinggi. Diperlukan lebih banyak penelitian untuk mengetahui apa kebutuhan perusahaan yang lebih matang, sebelum kebijakan menjauh dari mendukung perusahaan tahap awal. Dalam memeriksa implikasi penelitian baru-baru ini pada perusahaan kecil yang berdampak besar, kita harus menahan godaan untuk mengesampingkan program yang bermanfaat yang mendukung bisnis tahap awal.
\end{abstract}

Kata Kunci: Gazelle, perusahaan kecil pertumbuhan tinggi, perusahaan kecil berdampak tinggi.

\begin{abstract}
This study aims to find out whether there are signs that public policy is beginning to understand that it is not only in startup companies that can achieve high levels of growth. More research is needed to find out what company needs are more mature, before policies move away from supporting early stage companies. In examining the implications of recent research on small companies with a large impact, we must resist the temptation to rule out useful programs that support early-stage business.
\end{abstract}

Keywords: Gazelle, high growth small firms, high impact small firm.

\section{A. PENDAHULUAN}

Dalam beberapa tahun para ahli telah menulis sejumlah artikel yang menyoroti mengenai perusahaan kecil berdampak tinggi yang telah menunjukkan bahwa pertumbuhan, inovasi dan penciptaan lapangan kerja bukanlah satu-satunya tujuan tahap awal, bisnis teknologi tinggi, dan itu sebagai konsekuensi kebijakan publik harus ditinjau untuk memperhitungkan hal ini.

Praktik mengubah hasil penelitian menjadi kebijakan publik yang efektif penuh dengan kesulitan. Proses politik selalu mencari perbaikan cepat, ide besar berikutnya, yang akan mencapai hasil nyata dalam siklus politik jangka pendek. Ketika penelitian melempar temuan yang berbeda dengan ortodoksi saat ini, dalam hal ini bahwa perusahaan teknologi tinggi bukan satu-satunya sumber pertumbuhan yang tinggi, godaan untuk melihat ini sebagai momen eureka 
bisa menjadi terlalu besar. Desakan politis bahwa kebijakan publik baru harus 'berbasis bukti', secara paradoks, tidak membantu. Tekanan dari siklus politik berarti bahwa 'bukti' dapat diambil dari mana saja untuk mendukung respon kebijakan 'akal sehat', atau hasil penelitian setengah matang dapat dilarikan sebelum matang ke dalam perumusan kebijakan. Hal ini dapat mengakibatkan penurunan pemahaman yang realistis atas penelitian dan bukti.

Dalam perkembangan ekonomi, tekanan untuk hasil yang cepat sering menyulitkan para praktisi dan pembuat kebijakan untuk mengakui bahwa banyak intervensi kebijakan publik untuk mendukung bisnis adalah proble-matic, dan seringkali sangat sulit untuk mencapai hasil yang solid dan positif. Sebagai contoh, perlu waktu puluhan tahun untuk mengembangkan kebijakan yang efektif untuk meningkatkan akses ke keuangan untuk perusahaan tahap awal, baik di Eropa dan Amerika. Sementara ada pembicaraan mudah tentang 'praktik terbaik', ini masih merupakan bidang di mana ada lebih banyak pekerjaan yang harus dilakukan dan di mana ada jauh dari kesepakatan universal tentang apa yang seharusnya terdiri dari praktik terbaik. Kami melihat perkembangan baru sepanjang waktu, termasuk aplikasi keuangan malaikat bisnis dan crowdfunding yang semakin canggih.

\section{B. LANDASAN TEORI}

\section{Perusahaan Kecil}

Uni Eropa mengklasifikasi suatu perusahan berdasarkan jumlah karyawan adalah sebagai berikut :perusahaan mikro (0-9 karyawan), perusahaan kecil (10-49 karyawan) dan perusahaan menengah (50-249 karyawan). Semua ini dapat digabungkan menjadi satu kategori tunggal "usaha kecil dan menengah" atau UKM.

Borch \& Arthur (1995) mengidentifikasi bahwa tidak ada konsep seperti bisnis kecil yang khas; sebaliknya heterogenitas sektor usaha kecil harus ditekankan. Ukuran obyektif ukuran, seperti jumlah karyawan, omset penjualan, profitabilitas, kekayaan bersih dll. Ketika diperiksa di tingkat sektoral, berarti bahwa di beberapa sektor semua perusahaan dapat dianggap kecil, sedangkan di sektor lain mungkin tidak ada perusahaan yang kecil.

Upaya untuk merumuskan definisi kualitatif dari perusahaan kecil telah dibuat. Apa yang mendasari upaya ini adalah asumsi utama bahwa perusahaan kecil pada dasarnya berbeda dengan perusahaan besar (Blackburn \& Kovalainen, 2009). Definisi yang paling banyak diterima, yaitu dari Beesley \& Hamilton (1984), menunjukkan bahwa perusahaan kecil memenuhi kriteria 
berikut: mereka memiliki pangsa pasar yang relatif kecil; mereka dikelola oleh pemilik atau pemilik-bagian dengan cara yang dipersonalisasi; dan tidak melalui media struktur manajemen formal; mereka mandiri, dalam arti tidak membentuk bagian dari perusahaan yang lebih besar.

\section{Perusahaan Dengan Pertumbuhan Tinggi}

Perusahaan dengan pertumbuhan tinggi sering disebut sebagai 'gazelle', istilah yang diperkenalkan oleh Birch (1981). Namun, baru-baru ini sekarang lebih sering dikaitkan hanya dengan perusahaan muda, dan biasanya kecil, pertumbuhan tinggi. OECD mendefinisikan gazelle sebagai bagian dari perusahaan pertumbuhan tinggi yang berusia hingga lima tahun. Juga istilah 'gorila' saat ini digunakan ketika mendefinisikan perusahaan dengan pertumbuhan tinggi. istilah ini mengacu pada subset dari perusahaan-perusahaan dengan pertumbuhan tinggi yang ditandai sebagai perusahaan baru yang tumbuh dengan sangat cepat menjadi perusahaan internasional yang besar (Prashantham \& Birkinshaw, 2008).

Penelitian perusahaan yang berkembang sering gagal menangkap efek pertumbuhan terhadap ekonomi. Perusahan yang berkembang dapat berkontribusi dalam bentuk pertumbuhan lapangan kerja, inovasi baru, pendapatan pajak dan ekspor. David Birch meneliti dampak pertumbuhan perusahaan terhadap lapangan kerja. Salah satu aspek karyanya berfokus pada klasifikasi berbagai jenis (umur dan ukuran) perusahaan. Dia menemukan bahwa hampir $70 \%$ dari pekerjaan baru selama periode delapan tahun diciptakan oleh perusahaan dengan 20 atau lebih sedikit karyawan (Birch, 1981). Dia juga mencatat bahwa pencipta pekerjaan relatif muda; sekitar 80 persen pekerjaan pengganti diciptakan oleh perusahaan yang berusia empat tahun atau lebih muda. Birch terus mempelajari penciptaan lapangan kerja dan pada 1990-an Birch menyarankan bahwa mungkin bukan perusahaan besar atau kecil yang penting untuk pertumbuhan lapangan kerja tetapi grazelle.

Dia mengusulkan bahwa gazelle tidak dapat ditandai oleh ukuran. gazelle bergerak antara kecil dan besar dengan cepat pada berbagai waktu di kedua arah dan untuk mengklasifikasikan mereka berdasarkan ukurannya adalah kehilangan karakteristik unik mereka, inovasi hebat dan pertumbuhan lapangan kerja yang cepat (Henrekson dan Johansson, 2010). Henrekson dan Johansson menyimpulkan bahwa sejumlah kecil perusahaan yang sedang berjalan menciptakan bagian besar yang tidak proporsional dari semua pekerjaan baru di Amerika Serikat. 
Dalam studi lain Haltiwanger, Jarmin dan Miranda (12013) menemukan bahwa gazelles bertanggung jawab atas semua pekerjaan baru di seluruh ekonomi. Studi Birch, serta banyak penelitian pertumbuhan dan pekerjaan lainnya, tidak mempertimbangkan perusahaan mana yang justru menciptakan pekerjaan. Studi-studi tersebut biasanya mempertimbangkan perusahaan yang tumbuh sebagai satu kelompok dan menghitung peningkatan kotor pekerjaan baru. Dengan demikian temuan biasanya mencakup juga perusahaan yang hanya berkontribusi sedikit atau tidak sama sekali terhadap penciptaan lapangan kerja. Storey (1992) menemukan bahwa 53 persen, bukannya 82 persen pekerjaan baru diciptakan oleh perusahaan dengan kurang dari 100 karyawan pada periode 1976-1992 ketika mereka membedakan antara pekerjaan baru di pabrik baru (pekerjaan baru). di lokasi baru perusahaan yang ada), dan pekerjaan baru di pabrik yang didirikan oleh perusahaan yang baru dimulai.

Perusahaan berdampak tinggi atau perusahaan pertumbuhan juga berinteraksi dengan ekonomi dalam banyak hal. Setidaknya tiga cara diidentifikasi dalam literatur ekonomi: melalui inovasi, pertumbuhan produktivitas, atau perubahab lapangan kerja. Perusahaan berdampak tinggi dapat membuat inovasi atau menggunakannya. Dampak produktivitas juga penting, tetapi jauh lebih sulit untuk mengukur dan mengidentifikasi sumber perubahan produktivitas. Jenis interaksi ketiga perubahan lapangan kerja penting dan lebih mudah diukur. Oleh karena itu, literatur tentang dinamika perusahaan (masuk dan keluar) dan pertumbuhan lapangan kerja sangat membantu karena menghubungkan kedua kegiatan ini.

Toivonen, Parsons and Tracy (2008), mengembangkan konseptualisasi alternatif dari perusahaan berdampak tinggi yang mempertimbangkan penjualan dan pertimbangan pekerjaan. Mereka mendefinisikan perusahaan berdampak tinggi sebagai perusahaan di mana penjualan meningkat dua kali lipat selama periode 4 tahun terakhir dan yang memiliki kuantifier pertumbuhan lapangan kerja 2 atau lebih besar pada periode yang sama.

Pengukur pertumbuhan lapangan kerja atau employment growth quantifier (EGQ) adalah produk dari perubahan absolut dan persen dalam pekerjaan selama periode 4 tahun, yang dinyatakan sebagai desimal, dan digunakan untuk mengurangi dampak yang tidak menguntungkan dari mengukur perubahan pekerjaan hanya dalam persen atau absolut istilah, karena mantan mendukung perusahaan kecil dan bisnis besar yang terakhir. Jelas sementara konseptualisasi ini mencakup pertumbuhan perusahaan, itu tidak termasuk penciptaan kekayaan 
atau inovasi (penggunaan atau penciptaan mereka). Makalah penelitian ini menggunakan definisi perusahaan dampak tinggi yang dibuat oleh Toivonen et al (2009)

\section{METODE}

Penelitian ini dilakukan dengan meggunakan metode analisis kualitatif dengan melakukan studi literatur dengan mengumpulkan data sekunder tentang perusahaan-perusahaan kecil yang memiliki pertumbuhan dan dampak tinggi dan mempelajari dampaknya bagi pertumbuhan ekonomi dan kebijakan publik.

\section{HASIL DAN PEMBAHASAN}

Ada kesepakatan umum tentang pentingnya perusahaan kecil pertumbuhan tinggi, 'gazelles', yang mendorong pertumbuhan di ekonomi modern. Begitu nilai perusahaan semacam itu telah diakui oleh penelitian, respons dari proses politik adalah menginginkan lebih dari mereka, dan mencari tuas kebijakan untuk mewujudkannya. Pengalaman itu beragam. Fenomena Lembah Silikon dan dinamika inovasi teknis, yang terkait dengan revolusi komputer dan kemajuan modern dalam ilmu kedokteran, menuntun pada kebijaksanaan yang diterima bahwa perusahaan teknologi tinggi, perusahaan pemula, dipimpin oleh generasi baru wirausaha, adalah dasar dari pertumbuhan borjuis di ekonomi secara keseluruhan.

Kebijakan publik merespons dengan mencoba meningkatkan skala kegiatan kewirausahaan tersebut. Ini menghasilkan beberapa inisiatif berharga, terutama di bidang akses ke keuangan, tetapi juga menyebabkan banyak program yang salah dipahami untuk menciptakan perkembangan baru berdasarkan model Lembah Silikon di tempat-tempat yang tidak pantas. Pemerintah daerah dan nasional juga cenderung membatasi minat mereka pada program kebijakan yang hanya berkonsentrasi pada bisnis pemula dan tahap awal.

Penelitian selanjutnya menunjukkan bahwa perusahaan kecil yang mencapai tingkat pertumbuhan tinggi tidak terbatas pada tahap awal spektrum. Studi Toivonen et al. (2009) yang dilakukan untuk Administrasi Bisnis Kecil di AS menunjukkan bahwa usia rata-rata perusahaan berdampak tinggi tersebut adalah 25 tahun, dan bahwa mereka berasal dari berbagai sektor, tidak hanya teknologi tinggi. Penelitian Brown, Mawson \& Mason (2017) dan penelitian yang digariskan oleh Coad et al. (2014), juga menunjukkan pertumbuhan tinggi menjadi ciri perusahaan yang sudah mapan. 
Kami belum tahu seberapa berguna penelitian terbaru ini untuk menyusun kebijakan yang efektif. Pekerjaan lebih lanjut diperlukan untuk menjawab pertanyaan seperti:

1. Apa kesamaan karakteristik, jika ada, yang lebih matang, perusahaan berdampak tinggi?

2. Apakah fenomena pertumbuhan di perusahaan yang sudah mapan adalah umum untuk semua sektor dan wilayah?

3. Bisakah metodologi dirancang untuk mengidentifikasi perusahaan seperti itu?

4. Apa faktor-faktor yang memicu pertumbuhan di perusahaan-perusahaan ini?

5. Apakah ada bukti bahwa pertumbuhan perusahaan dengan potensi pertumbuhan tinggi tersebut dihambat oleh kegagalan pasar?

6. Apakah kegagalan pasar ini rentan terhadap intervensi kebijakan publik yang korektif?

Sampai kita mulai menemukan jawaban untuk pertanyaan-pertanyaan ini, upaya untuk merancang kebijakan masih terlalu dini. Namun, seperti yang ditunjukkan oleh Coad et al (2014), ada tanda-tanda bahwa kereta musik mungkin sudah mulai bergulir. Informasi baru tentang perusahaan-perusahaan berdampak besar pastilah mengarah pada tinjauan kebijakan yang ada, tetapi ini harus tentang mencari tahu lebih lanjut dan melihat apakah kebijakan publik dapat membantu. Sama sekali tidak ada alasan untuk mundur dari program dukungan yang efektif untuk perusahaan tahap awal. Penulis tidak akan membenci tingkat kegagalan perusahaan seperti itu tinggi, dan ini membuat kebijakan untuk memelihara mereka secara politis kadangkadang sulit. Tetapi ada beberapa cara untuk mengatasi hal ini, dan kami tahu bahwa tanpa intervensi kebijakan publik, skala kegiatan bisnis pemula akan lebih rendah, dan kami tahu bahwa perusahaan tahap awal telah memberikan kontribusi besar terhadap pertumbuhan ekonomi dalam beberapa dekade terakhir. Berapa banyak start-up yang bermasalah berlangsung dalam beberapa bentuk untuk mencapai pertumbuhan tinggi di tahun-tahun berikutnya.

\section{E. KESIMPULAN}

Sebuah langkah menjauh dari program tahap awal juga akan memiliki konsekuensi yang tidak menguntungkan di mana kelompok klien terdiri dari komunitas yang kurang beruntung di mana memulai bisnis dapat menjadi alternatif praktis untuk menemukan pekerjaan. Banyak kebijakan yang dimaksudkan untuk mendorong sektor perusahaan kecil di Eropa didasarkan pada pengalaman dari AS, didorong oleh keinginan pihak pembuat kebijakan Eropa untuk mencocokkan kinerja ekonomi AS. Namun, fitur penting dari program yang dikelola oleh 
Administrasi Bisnis Kecil di Washington DC adalah bahwa mereka cenderung memiliki daya tahan, menghindari perubahan yang sering dimaksudkan untuk menangkap ide baru terbaru. Ini adalah sesuatu yang sepertinya kita lewatkan di Eropa. Dalam memeriksa implikasi penelitian baru-baru ini pada perusahaan kecil yang berdampak besar, kita harus menahan godaan untuk mengesampingkan program yang bermanfaat yang mendukung bisnis tahap awal.

\section{DAFTAR PUSTAKA}

Beesley, M. E., \& Hamilton, R. T. (1984). Small firms' seedbed role and the concept of turbulence. The Journal of Industrial Economics, 217-231.

Birch, D. (1981). Who Creates Jobs?. The public Interest, 65, 3-14

Blackburn, R., \& Kovalainen, A. (2009). Researching small firms and entrepreneurship: Past, present and future. International Journal of Management Reviews, 11(2), 127-148.

Borch, O. J., \& Arthur, M. B. (1995). Strategic networks among small firms: implications for strategy research methodology. Journal of Management Studies, 32(4), 419-441.

Brown, Mawson dan Mason, R., Mawson, S., \& Mason, C. (2017). Myth-busting and entrepreneurship policy: the case of high growth firms. Entrepreneurship \& Regional Development, 29(5-6), 414-443.

Coad, A., Daunfeldt, S. O., Hölzl, W., Johansson, D., \& Nightingale, P. (2014). High-growth firms: introduction to the special section. Industrial and Corporate Change, 23(1), 91112.

Haltiwanger, J., Jarmin, R. S., \& Miranda, J. (2013). Who creates jobs? Small versus large versus young. Review of Economics and Statistics, 95(2), 347-361.

Henrekson, M., \& Johansson, D. (2010). Gazelles as job creators: a survey and interpretation of the evidence. Small business economics, 35(2), 227-244.

Prashantham, S., \& Birkinshaw, J. (2008). Dancing with gorillas: How small companies can partner effectively with MNCs. California management review, 51(1), 6-23.

Storey, D. J. (1992). The State of Small Business: A Report of the President.

Toivonen, T., Paasio, A., \& Sinervo, P. (2009, September). High-Impact Firms in European Software Business. In Proceedings of the 4th European Conference on Entrepreneurship and Innovation (pp. 525-529). 